\title{
PEMBUATAN HANDYCRAFT DARI BAMBU UNTUK PENINGKATAN KOMODITAS KERAJINAN BAMBU PADA KARANG TARUNA DI KELURAHAN JEBRES KECAMATAN JEBRES KOTA SURAKARTA
}

\author{
Dinna Riana ${ }^{1)}$ \\ I Gusti Putu Diva Awatara ${ }^{2)}$ \\ Joko Sekti Riyadi ${ }^{3)}$ \\ STIE Adi Unggul Bhirawa Surakarta \\ elhasaprimitifbatik@gmail.com
}

\begin{abstract}
ABSTRAK
Bambu merupakan jenis tanaman yang sering kita jumpai di negeri tercinta ini. Tumbuhan satu ini sangat cocok tumbuh di negeri ini karena letak geografis dan iklimnya, sehingga pertumbuhan dan persebarannya sangat cepat dan mudah. Kelebihan dari bambu adalah batang yang lentur sehingga menyebabkan tidak mudah patah, dinding kayunya yang keras serta pemanfaatannya bisa berumur panjang. Disamping itu juga bahannya mudah dicari. Alasan inilah bambu dioptimalkan sebagai handycraft yang mempunyai nilai lebih walaupun pengerjaan lebih rumit. Tujuan dari pengabdian masyarakat ini adalah untuk memberikan pendampingan pembuatan handycraft bambu pada pengrajin bambu untuk meningkatakan komoditas kerajinan bambu, selain itu pendampingan ini juga dapat memberi nilai labih pada produk bambu serta meningkatkan harga jual kerajinan bambu yang semula hanya dipakai untuk kebutuhan sehari-hari saja. Hasil pengabdian ini menunjukkan bahwa anggota Karang Taruna di Kelurahan Jebres Kecamatan Jebres Kota Surakarta dapat meningkatkan kerajinan handycraft berbahan baku bambu, menumbuhkan kreativitas anggota Karang Taruna dan meningkatkan nilai jual tanaman bambu yang semula hanya digunakan untuk kebutuhan sehari-hari.
\end{abstract}

Kata kunci: handycraft, bambu, kerajinan, karang taruna

\section{Pendahuluan}

Bambu merupakan jenis tanaman yang sering kita jumpai di negeri tercinta ini. Tumbuhan satu ini sangat cocok tumbuh di negeri ini karena letak geografis dan iklimnya, sehingga pertumbuhan dan persebarannya sangat cepat dan mudah. Kelebihan dari bambu adalah batang yang lentur sehingga menyebabkan tidak mudah patah, dinding kayunya yang keras serta pemanfaatannya bisa berumur panjang. Disamping itu juga bahannya mudah dicari. Alasan inilah bambu dioptimalkan sebagai handycrat yang mempunyai nilai lebih walaupun pengerjaan lebih rumit.

Dalam kehidupan masyarakat pedesaan di Indonesia, bambu memiliki peranan yang sangat penting. Bahan bambu memiliki sifat-sifat yang baik untuk dimanfaatkan, antara lain batangnya kuat, ulet, lurus, rata, keras, mudah dibelah, mudah dibentuk dan ringan. Selain itu harga perolehan bambu juga relatif murah dibandingkan dengan bahan bangunan lain karena banyak ditemukan di sekitar pemukiman pedesaan (Setiawan, 2010).

Produk handycraft ini mempunyai peluang yang sangat potensial dan bagus di pasar, sehinga dapat menumbuhkan wirausaha baru untuk membuka peluang usaha dan mengurangi tingkat urbanisasi masyarakat di kota tersebut. Tetapi, pembuatan dalam bentuk handycraft masih dilakukan secara sederhana serta dilakukan secara terbatas dengan skala ekonomi kecil Hal tersebut juga dibarengi dengan proses pemasaran yang masih sangat sederhana, dimana para penghasil hanya melakukan pemasaran sebatas menjual hasil produksinya ke pasar tradisional di wilayah sekitar Kecamatan Jebres yang dianggap ramai tanpa mencoba mengembangkan pola perencanaan usaha, pola produksi dan pola pemasarannya lebih jauh lagi.

Guna adanya regenerasi yang lebih kreatif dan punya daya juang tinggi maka karang taruna bisa menjadi sumberdaya daya untuk mengembangkan potensi keajinan bambu tersebut, Berdasar pengamatan dan pertemuan pendahuluan pada karang taruna di kelurahan Jebres Kecamatan Jebres Surakarta, para kaum muda tertarik untuk mengembangkan potensi daerah terutama komoditas bambu untuk dibuat kerajinan tangan atau handycraft yang mempunyai nilai jual lebih tinggi. Pelatihan akan 
dilaksanakan di Kelurahan Jebres Kecamatan Jebres Surakarta, peserta pelatihan ditargetkan sebanyak 25 orang dari anggota karang taruna di Kelurahan Jebres, Kecamatan Jebres Surakarta.

Pengabdian ini bertujuan untuk: Karang taruna kelurahan Jebres Kecamatan Jebres Surakarta agar dapat mengembangkan nilai jual komoditas bambu dan Karang taruna kelurahan Jebres Kecamatan Jebres Surakarta agar dapat melakukan kegiatan praktek pembuatan handycraft dari bambu guna menambah nilai jual dari kerajinann bambu dan menciptakan peluang berwirausaha.

\section{Metode}

Pemanfaatan bambu yang dilakukan adalah setelah mengikuti pelatihan handycraft dari bambu ini diharapkan karang taruna kelurahan Jebres Kecamatan Jebres dapat meningkatkan nilai jual bambu dan diharapkan munculnya pengrajin baru dan peluang berwirausaha sehingga mengurangi angka pengangguran di Surakarta. Pemanfaatan bambu yang digunakan adaah dijadikan berbagai asesoris yang dapat digunakan untuk berbagai kebutuhan rumah tangga.

Metode kegiatan yang akan dilakukan untuk tercapainya tujuan pengabdian kepada masyarakat ini adalah metode ceramah, diskusi dan demonstrasi praktik langsung di lapangan yang didasari oleh evaluasi awal sebagai landasan untuk menentukan posisi pengetahuan kelompok sasaran mengenai kemampuan memanfaatkan bambu melalui penerapan konsep optimalisasi pelatihan kepada karang taruna kelurahan Jebres Kecamatan Jebres.

Pelatihan handycraft dari bambu ini diharapkan karang taruna kelurahan Jebres Kecamatan Jebres dapat berwirausaha. Kegiatan ini meliputi dua tahap utama yaitu, pengembangan teknologi pemanfaatan bambu dan peningkatan sumber daya manusia. Kegiatan pengembangan teknologi ini terdiri atas: ((i) identifikasi lokasi kegiatan; (ii) sosialisasi kegiatan di tingkat kelurahan; (iii) implementasi pengembangan teknologi. Peningkatan sumber daya manusia yang dilakukan adalah: (i) studi banding ke lokasi percontohan pemanfaatan pekarangan; (ii) Pendampingan kegiatan kelompok karang taruna.

\section{Hasil dan Pembahasan}

Pelatihan peningkatan nilai tambah pemanfaatan bambu dilaksanakan ditingkat karang taruna Kelurahan Jebres Kecamatan Jebres Kota Surakarta. Pertemuan dengan anggota karang taruna dilakukan untuk merencanakan kegiatan secara teknis. Bambu sampai saat ini sudah dimanfaatkan sangat luas di masyarakat mulai dari penggunaan teknologi yang paling sederhana sampai pemanfaatan teknologi tinggi pada skala industri. Pemanfaatan di masyarakat umumnya untuk kebutuhan rumah tangga dan dengan teknologi sederhana, sedangkan untuk industri biasanya ditujukan untuk orientasi eksport.

Berbagai kerajinan dan handycraft dibuat dari bambu antara lain: tempat pulpen, gantungan kunci, cup lampu, keranjang, tas, topi dan lain-lain. Dalam hal ini yang dibutuhkan adalah keterampilan dan kreativitas dalam memanfaatkan bambu. Pola pemanfaatan bambu oleh masyarakat secara nyata menimbulkan dampak/gangguan ekologi pada bambu. Supriyadi dan Suryaatmaja (2008) menegaskan bahwa di beberapa lokasi kawasan hutan bambu TNAP ditemukan kerusakan parah dan beberapa rumpun sudah rusak dan tidak bisa tumbuh lagi permudaannya. Bahkan ada lokasi yang dulu diketahui sebagai habitat bambu namun sudah tidak ditemukan lagi adanya rumpun bambu yang tumbuh. Kerusakan ini terjadi terutama di wilayah yang berbatasan langsung dengan kawasan kegiatan pertanian/perkebunan masyarakat yang berada di dalam zona penyangga dan wilayah yang berbatasan langsung dengan laut memiliki aksesibilitas jauh lebih mudah karena transportasi bambu dilakukan dengan perahu dan pengawasan petugas yang rendah, sehingga pengambilan bambu sangat intensif ( 20 - 25 batang ditebang dalam satu rumpun.

Kelurahan Jebres memiliki potensi sumber daya alam dan manusia yang melimpah. Hal ini ditinjau dari ketersediaan dan potensi lahan serta potensi Kelurahan Jebres sebagai salah satu desa dengan jumlah penduduk terbesar di Kecamatan Jebres, Kota Surakarta sehingga berdampak pada percepatan pembangunan Kelurahan bila dioptimalkan dengan tepat. Namun, pembangunan Keluruhan belum terlaksana secara optimal oleh karena beberapa hambatan yang disebabkan oleh keinginan masyarakat untuk bertahan pada pola aktivitas keseharian secara tradisional. Salah satu masalah yang dihadapi dan belum tertangani oleh masyarakat diantaranya adalah terbatasnya 
pengetahuan dan kecapakan masyarakat dalam pengelolaan produk kerajinan bambu sebagai salah satu komiditi sumber daya alam terbesar di Kelurahan Jebres Kecamatan Jebres Kota Surakarta. Masyarakat Kelurahan Jebres mengemukakan bahwa beberapa hal yang menjadi permasalahan dalam pengelolaan produk kerajinan bambu di Kelurahan Jebres Kecamatan Jebres Kota Surakarta diantaranya adalah belum terkoordinasinya anggota pengrajin bambu untuk menjadi sebuah komunitas pengrajin bambu yang memungkinkan terciptanya beraneka ragam bentuk bentuk produk kerajinan bambu sehingga bernilai jual lebih, selain itu para pengrajin bambu juga hanya sebatas memiliki kecakapan keterampilan kerajinan bambu yang terbatas dan belum berkembang ke arah kreasi industri kreatif kerajinan bambu, padahal hal ini memungkinkan bagi percepatan kemajuan perekonomian masyarakat terutama yang menopang kehidupan dari sumber daya alam bambu. Pengelolaan produksi bambu menjadi sebuah produk kerajinan juga dinilai menjadi hal yang penting dalam proses pelestarian pohon bambu sehingga dalam proses penanaman dan pemeliharaannya memiliki nilai tambah. Dalam hal ini, maka masyarakat ditinjau untuk lebih aktif memelihara keberadaan sumber daya alam bambu sehingga dapat menjadi salah satu potensi perekonomian masyarakat yang bernilai.

Kendala pemasaran yang dihadapi pengrajin mebel bambu ini adalah kepastian pasar, karena selama ini pemasaran melalui showroom masih menjadi andalan, meskipun pada beberapa pengrajin pemasaran melalui showroom menjadi pilihan kedua karena sebagian besar produknya dapat dipasarkan keluar daerah. Meskipun kerajinan mebel bambu menjadi primadona dan salah satu ikon produk usaha, namun ikon tersebut ternyata tidak berjalan seiringan dengan produk itu sendiri karena tidak ada system pelabelan sehingga produk yang dipasarkan tidak memiliki label. Pelabelan akan dipasang oleh pedagang perantara/ pemesan, dengan nama dan daerah lokasi asal pedagang perantara/pemesan, sehingga pada saat mebel bambu dipasarkan ke konsumen maka label yang terpasang adalah nama/usaha dari pedagang perantara/pemesan dan bukannya nama sanggar bambu/pengrajin bambu.

Lokasi usaha kerajinan bambu sangat dipengaruhi oleh lokasi keberadaan bahan baku utama (bambu) dan tenaga pengrajin, hal ini akan berpengaruh terhadap kelangsungan proses produksi dan penekanan biaya penyediaan bahan baku. Wilayah di Kecamatan Jebres memiliki potensi bambu wulung yang cukup besar, sehingga selama ini kebutuhan bahan baku masih dapat diperoleh dari sekitar lokasi usaha. Keberadaan lokasi usaha di pinggir jalan memberikan nilai lebih bagi pengrajin, khususnya dalam pemasaran produk, sehingga memudahkan dalam proses pengangkutan produk ke pembeli/konsumen. Penataan ruang dalam kegiatan usaha tidak diatur secara detail, namun tetap dilakukan pemisahan pada beberapa kegiatan proses produksi seperti areal penjemuran, bangunan penyimpanan bahan baku, ruang proses produksi, ruang penyimpanan produk dan ruang pamer. Banyak diantara pengrajin yang hanya menempatkan seluruh kegiatan proses produksi dalam bangunan semi permanen yang terhindar dari sinar matahari secara langsung dan terhindar dari hujan. Berdasarkan hasil pengamatan, secara rata-rata kegiatan usaha kerajinan mebel bambu memerlukan areal seluas $138 \mathrm{~m}$, tidak termasuk areal/tanah untuk pengeringan bambu. 


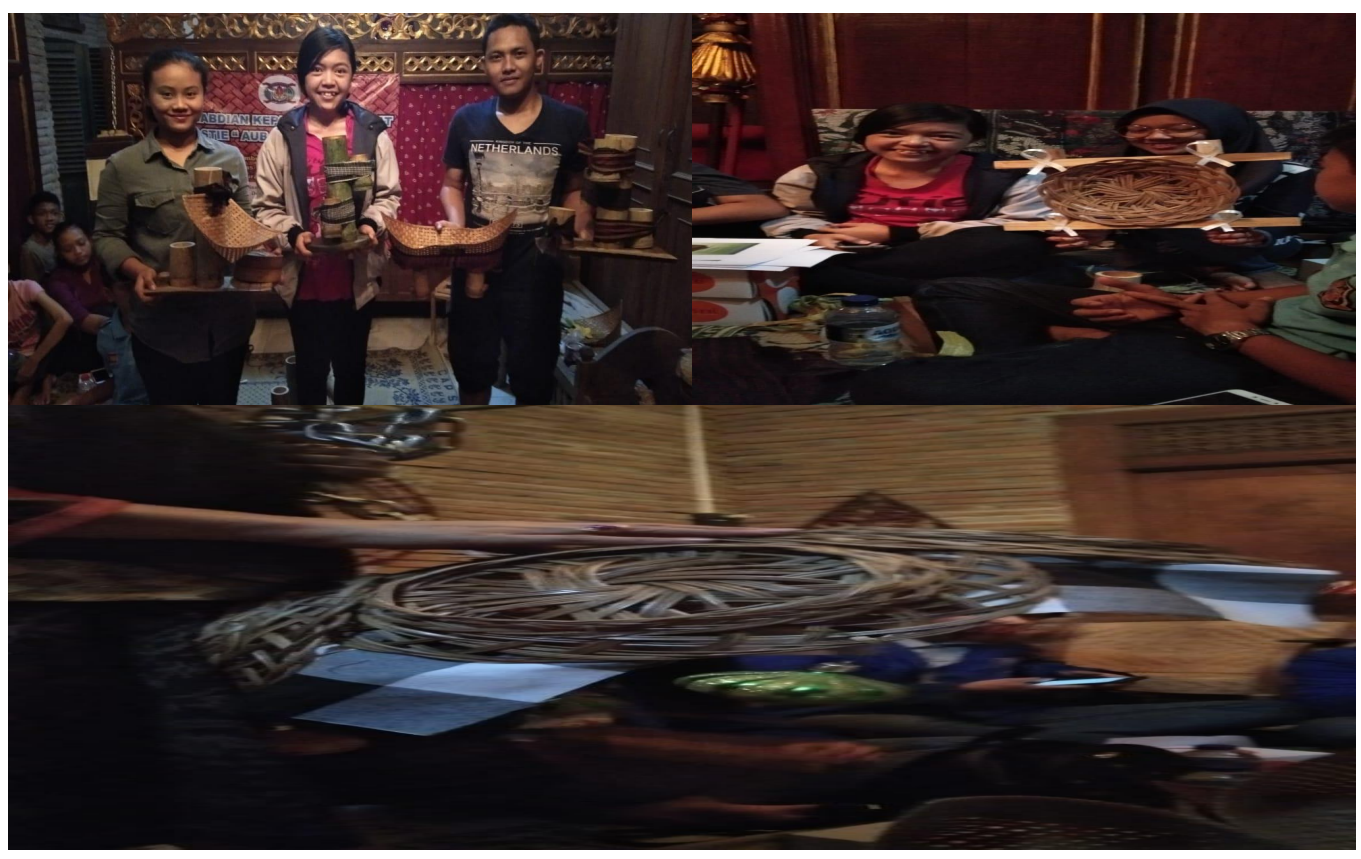

Gambar 1. Pembuatan Kerajinan Bambu untuk Karangtaruna

Evaluasi kegiatan pengabdian dilakukan dengan cara yaitu membandingkan pengetahuan dan pemahaman warga sebelum dan sesudah kegiatan. Secara umum dapat menunjukkan bahwa terjadi peningkatan pengetahuan peserta mengenai Pembuatan Handycraft dari Bambu Untuk Peningkatan Komoditas Kerajinan Bambu Pada Karang Taruna di Kelurahan Jebres Kecamatan Jebres Kota Surakarta.

Peserta memahami bahwa pemanfaatan lahan pekarangan secara optimal dapat membantu ketahanan pangan keluarga. Pada Tabel 4.10 menggambarkan kriteria dan indikator keberhasilan pelaksanaan kegiatan pengabdian ini.

Strategi pemberian materi baik waktu maupun tempat terutama penyuluhan di lapangan dirasakan sangat mendukung kegiatan karena peserta mempunyai banyak waktu untuk mengikuti penyuluhan. Beberapa faktor yang dapat mendorong terlaksananya kegiatan pengabdian ini adalah peserta terutama pemuda dan pemudi anggota karang taruna sangat bersemangat mengikuti acara pelatihan. Peserta merupakan anggota karang taruna di Kelurahan Jebres Kecamatan Jebres Kota Surakarta, dan memahami mengenai pentingnya peningkatan komoditas kerajinan bambu pada karang taruna di Kelurahan Jebres Kecamatan Jebres Kota Surakarta, selain itu yang tidak kalah penting adalah kerjasama yang baik dari pihak Kelurahan untuk mendukung dalam penyediaan sarana dan mengundang peserta sebagai perwakilan tiap RW. Faktor yang dapat menjadi penghambat dalam pelaksanaan pengabdian ini adalah waktu yang singkat dalam setiap materi sehingga tidak seluruh fasilitas dan potensi dapat ditunjukkan oleh peserta.

Tabel 1. Kriteria dan Indikator Keberhasilan Kegiatan

\begin{tabular}{|c|c|l|}
\hline No & Kriteria & \multicolumn{1}{c|}{ Indikator } \\
\hline $\mathbf{1}$ & Tingkat Partisipasi & $\begin{array}{l}\text { Kegiatan pelatihan dihadiri peserta yang jumlahnya mencapai lebih } \\
\text { dari 25 anggota karang taruna yang juga merupakan perwakilan dari } \\
\text { tiap RW di Kelurahan Jebres Kecamatan Jebres Kota Surakarta }\end{array}$ \\
\hline $\mathbf{2}$ & $\begin{array}{l}\text { Tingkat pemahaman } \\
\text { peserta terhadap } \\
\text { materi pelatihan }\end{array}$ & $\begin{array}{l}\text { Peserta aktif bertanya dan sering mengemukakan saran-saran serta ide- } \\
\text { ide atau pengetahuan yang mereka punya serta meminta saran ilmiah } \\
\text { terhadap ide yang mereka kemukakan. Peserta sangat serius mengikuti }\end{array}$ \\
\hline
\end{tabular}




\begin{tabular}{|c|l|l|}
\hline & & $\begin{array}{l}\text { pelatihan baik indoor (ceramah) maupun outdoor peninjauan ke } \\
\text { lapangan, bimbingan teknis. }\end{array}$ \\
\hline 3 & Dampak pelatihan & $\begin{array}{l}\text { Dari tahapan demi tahapan pelatihan ini terlihat antusias peserta dan } \\
\text { terlihat diskusi semakin hidup dan peserta menguasai permasalahan } \\
\text { yang mendasar mengenai pembuatan handycraft dari bambu untuk } \\
\text { peningkatan komoditas kerajinan bambu pada karang taruna di } \\
\text { Kelurahan Jebres Kecamatan Jebres Kota Surakarta. }\end{array}$ \\
\hline 4 & Kesesuaian materi & $\begin{array}{l}\text { Materi penyuluhan sangat relevan mengingat potensi pembuatan } \\
\text { handycraft dari bambu untuk peningkatan komoditas kerajinan bambu } \\
\text { pada karang taruna di Kelurahan Jebres Kecamatan Jebres Kota } \\
\text { Surakarta yang belum termanfaatkan secara optimal. }\end{array}$ \\
\hline
\end{tabular}

Sumber: data primer diolah (2018)

Tindak lanjut dari kegiatan ini adalah perlunya adanya kegiatan pelatihan pada peningkatan diversifikasi produk, motivasi untuk berwirausaha, pemasaran dan sistem pelaporan keuangan terutama terkait dengan memisahkan penghitungan pendapatan yang dihasilkan dari peningkatan komoditas kerajinan bambu pada karang taruna di Kelurahan Jebres Kecamatan Jebres Kota Surakarta dengan pendapatan dari keluarga.

\section{Kesimpulan}

Hasil pengabdian ini menunjukkan bahwa pembuatan handycraft dari bambu untuk peningkatan komoditas kerajinan bambu pada karang taruna di Kelurahan Jebres Kecamatan Jebres Kota Surakarta dapat berjalan dengan baik; pemuda dan pemudi Karang Taruna di Kelurahan Jebres Kota Surakarta mampu termotivasi untuk membuat komoditas kerajinan bambu agar dapat memberikan nilai tambah serta pemuda dan pemudi Karang Taruna di Kelurahan Jebres Kota Surakarta mampu memaksimalkan peningkatan komoditas kerajinan bambu pada karang taruna di Kelurahan Jebres Kecamatan Jebres Kota Surakarta.

\section{Daftar Pustaka}

Arif dan Wibowo. 2004. Akuntansi Untuk Bisnis Usaha Kecil dan Menengah. Grasindo, Jakarta. Bansal, AK \& Zoolagud, SS. 2002. Bamboo Composites: Material of The Future. Journal of Bamboo and Rattan. 1:119-130.

Dransfield S, Widjaja, E A. (Editors). 1995. Plant resources of South-East Asia No.7 Bambos. Backhuys Publishers, Leiden

Hoogendoorn JC, Benton A. 2014. Bamboo and Rattan Production and The Implications of Globalization. In: Nikolakis W, Innes J, Eds. Forests and Globalization: Challenges and Opportunities For Sustainable Development. London: Routledge, 166-184.

Liese W and Ko"hl M. 2015. Bamboo: The Plant and Its Uses. Tropical Forestry. Springer, Basel, Switzerland.

Morisco, 2006. Teknologi Bambu. Bahan Kuliah Magister Teknologi Bahan Bangunan. Program Studi Teknik Sipil Universitas Gadjah Mada, Yogyakarta.

Nadeak M N. 2009. Deskripsi budidaya dan pemanfaatan bambu di Kelurahan Balumbang Jaya Kecamatan Bogor Barat dan Desa Rumpin Kecamatan Rumpin Kabupaten Bogor, Jawa Barat.

Saefudin dan T, Rostiwati. 2010. Pemilihan bahan vegetative untuk penyediaan bibit bambu hitam. Jurnal Tekno Hutan Tanaman. 3 (1): 23-28.

Setiawan, B. 2010. Strategi Pengembangan Usaha Kerajinan Bambu di Wilayah Kampung Pajeleran Sukahati Kecamatan Cibinong. Kabupaten Bogor. Jurnal Manajemen dan Organisasi. Vol 1, No. 2, Hal. 135-147. 
Song X, Zhou G, Jiang H, Yu S, Fu J, Li W, Wang W, Ma Z, Peng C. 2011. Carbon Sequestration by Chinese Bamboo Forests and Their Ecological Benefits: Assessment of Potential, Problems, and Future Challenges. Environmental Reviews. 19:418-428.

Widjaja, EA, 2001, Identifikasi Jenis-jenis Bambu di Kepulauan Sunda Kecil, Pusat Penelitian dan Pengembangan Biologi, LIPI, Bogor, Indonesia.

Widjaja, E. A. dan Karsono. 2004. Keanekaragaman bambu di Pulau Sumba. Jurnal Biodiversitas, 6 (2): $95-99$.

Winarto, V. dan D. Ediningtyas. 2012. Mau Tahu Tentang Bambu? Buku. Kementerian Kehutanan. Jakarta.

Yani, A.P. 2014. Keanekaragaman bambu dan manfaatnya di Desa Tabalagan Bengkulu Tengah. Jurnal Gradien. 10 (2): 987-991. 